LETTER TO JMG

\title{
Functional and genetic studies demonstrate that mutation in the COX15 gene can cause Leigh syndrome
}

\author{
C E Oquendo, H Antonicka, E A Shoubridge, W Reardon, G K Brown
}

J Med Genet 2004;41:540-544. doi: 10.1136/jmg.2003.017426

eigh syndrome is a subacute necrotising encephalomyelopathy characterised by delayed onset of symptoms, -hypotonia, feeding difficulties, failure to thrive, motor regression, and brain stem signs. The main laboratory findings are raised lactate in the blood and cerebrospinal fluid, but the diagnosis is only confirmed by the presence of bilateral symmetrical lesions in the basal ganglia, thalamus, brain stem, and cerebellum. Leigh syndrome can result from a number of different defects in mitochondrial energy metabolism, most commonly deficiencies of cytochrome oxidase (COX), pyruvate dehydrogenase, NADH-ubiquinone oxidoreductase (Complex I) and ATP synthase. ${ }^{1}$ In patients with Leigh syndrome and cytochrome oxidase deficiency, the underlying genetic defect is usually a mutation in the SURFI gene, which maps to chromosome $9 q 34$ and encodes a cytochrome oxidase assembly factor. ${ }^{2}{ }^{3}$ In a small number of cases, Leigh syndrome and cytochrome oxidase deficiency have been found in patients with mutations in mitochondrial DNA (mtDNA $)^{45}$ and in one patient with mutations in the COX10 gene. ${ }^{6}$

Cytochrome oxidase is the terminal complex of the electron transport chain. It transfers electrons from cytochrome $c$ to molecular oxygen and contributes to the proton motive force used in the generation of ATP. The mammalian complex is composed of thirteen subunits, three encoded in mtDNA and ten in nuclear DNA. ${ }^{7}$ Some of the nuclear subunits have different isoforms, which are coded by multigene families and are expressed in different tissues and at different stages of development. ${ }^{8-14}$ The cytochrome oxidase complex contains four prosthetic groups, haeme $a$, haeme $a_{3}, \mathrm{Cu}_{\mathrm{A}}$ and $\mathrm{Cu}_{\mathrm{B}}$, which are essential for the redox reaction. Therefore, generation of a fully functional complex in the inner mitochondrial membrane requires: (a) transcription and translation of 13 proteins in two different compartments of the cell, $(b)$ correct assembly in the inner mitochondrial membrane with prosthetic groups, and (c) regulation of activity according to specific tissue and developmental requirements.

As a consequence of this complexity, it is not surprising that cytochrome oxidase deficiency is genetically and phenotypically highly heterogeneous. At present, a specific genetic diagnosis is made in only $\approx 50 \%$ of patients and the majority of these belong to the SURFl deficiency group. ${ }^{15}$ Mutations in other nuclear genes whose products are necessary for cytochrome oxidase biogenesis, such as

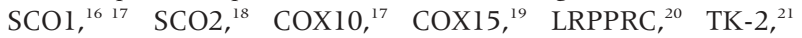
DGK-2, ${ }^{22}$ and thymidine phosphorylase, ${ }^{23}$ appear to be much less common. They have been associated with lactic acidosis and non-specific encephalopathy, in some cases co-existing with dysfunctions of other highly metabolic organs, such as heart, liver, kidney, and muscle.

We describe a patient who presented with Leigh syndrome as a result of cytochrome oxidase deficiency, in whom the underlying cause is a mutation in the COX15 gene, which codes for an enzyme involved in haeme $a$ biosynthesis. This is

\section{Key points}

- A patient with typical clinical and neuroradiological features of Leigh syndrome and cytochrome oxidase deficiency was found to have a mutation in the COX15 gene.

- This was initially identified by functional complementation of the enzyme defect in the patient's cells when COX15.1 protein was expressed from a retroviral vector.

- Mutation analysis of the COX15 gene revealed that the patient was homozygous for a missense mutation, cC700T (R217W). Both parents were demonstrated to be heterozygous for the mutation.

- Cytochrome oxidase deficiency, presenting as Leigh syndrome or as a non-specific encephalopathy, is genetically heterogeneous. Initial screening for functional complementation following expression of candidate gene products, as in this case, may be an efficient method for establishing a specific genetic diagnosis.

only the second patient described with a mutation at this locus and the clinical presentation differs significantly from the previously reported case, suggesting that this condition may be more variable in presentation than other defects of cytochrome oxidase assembly.

\section{MATERIALS AND METHODS}

\section{Patient cell cultures and derived cell lines}

Primary fibroblast cultures were established from skin biopsies and cultured in Dulbecco's Modified Eagle Medium-Nutrient Mixture F-12 Ham (DMEM/F12) supplemented with $10 \%$ fetal calf serum and antibiotics. Cultures were transduced with a retroviral vector containing the E6/E7 genes from the type-16 human papilloma virus. ${ }^{24}$ Transduced cells were cultured in high glucose Dulbecco's Modified Eagle's medium supplemented with $10 \%$ fetal calf serum.

\section{Biochemical analysis}

Primary fibroblasts were assayed for cytochrome oxidase activity spectrophotometrically by following the oxidation of reduced cytochrome $c$ as described previously. ${ }^{25}$ Cytochrome oxidase activity was also demonstrated by cytochemical staining based on mitochondrial localisation of polymerised diaminobenzidine following oxidation by cytochrome $c .{ }^{26}$ For complementation analysis with retroviral vectors, cellular extracts were prepared and cytochrome oxidase activity determined as described previously. ${ }^{27}$ In both protocols,

Abbreviations: COX, cytochrome oxidase; CS, citrate synthase 
cytochrome oxidase activity was related to protein concentration and citrate synthase (CS) activity. ${ }^{28}$

\section{Genetic analysis}

The coding regions of the SURF1, SCO1, SCO2, and COX10 genes were sequenced following amplification of cDNA or genomic DNA. There are two transcripts from the COX15 gene, COX15.1 and COX15.2, which are generated by alternative splicing. ${ }^{29}$ Primers specific for the COX15.1 variant were used to analyse the coding region of this gene in the patient. Messenger RNA was extracted from cultured fibroblasts using a Roche High Pure RNA Isolation Kit and cDNA made with an Omniscript ${ }^{\mathrm{TM}}$ RT Kit (Qiagen). Overlapping segments of the relevant coding regions were amplified by PCR, assessed by running an aliquot on $1 \%$ agarose gels and purified using a QIAquick PCR Purification Kit (Qiagen). Primers, product sizes, and annealing temperatures are presented in table 1 . The products were sequenced using $\mathrm{ABI}^{\mathrm{TM}}$ Big Dye Terminators (Applied Biosystems). Genomic DNA was prepared from fibroblasts using a Nucleon BACC2 Kit (Nucleon Biosciences). PCR primers were designed to span the relevant exon of the COX15 gene to confirm the mutation in genomic DNA and the PCR products were assessed on agarose gels, purified, and sequenced as before. In addition, the COX15 mutation was demonstrated by StyI digestion of the exon 5 PCR product.

\section{Retroviral transfection}

cDNAs corresponding to a number of human cytochrome oxidase assembly genes (COX11, COX15.1, COX17, OXAl, and PET191) were amplified by PCR and cloned into a retroviral expression vector pLXSH using the Gateway cloning system (Invitrogen). Retroviral constructs were used to transfect the GP+E86 ecotropic packaging cell line, ${ }^{30}$ and the virus produced was used to infect the amphotropic packaging cell line PA317 $7^{31}$ to create stable virus producing lines. Fibroblasts were infected by exposure to medium containing the virus in the presence of polybrene. ${ }^{32}$ Cultures were subsequently selected in $100 \mathrm{U} / \mathrm{ml}$ of hygromycin and surviving cells assayed for cytochrome oxidase activity.

\section{RESULTS}

\section{Clinical presentation}

The patient-a boy-was born at 41 weeks with a birth weight of $3.95 \mathrm{~kg}$. He was initially healthy, but from the age of seven months he was noticed to be hypotonic. Subsequently, he developed spasticity of the lower limbs, feeding difficulties, and horizontal nystagmus. At 15 months of age he showed motor regression, progressive microcephaly, and retinopathy. He was aware of his surroundings but unable to interact with others. At 2 years and 10 months, bloody bowel motions and loss of weight were reported, and these persisted until his death from pneumonia at 3 years, 11 months. There is no apparent history of consanguinity in the family.
Urea, electrolytes, ammonia, lysosomal enzymes, organic acids, very long chain fatty acids, and amino acid chromatography were all normal. Blood lactate was $5.2 \mathrm{mmol} / \mathrm{l}$ (normal range: 0.63-2.44) and cerebrospinal fluid lactate was $6.2 \mathrm{mmol} / \mathrm{l}$ (normal range: 0.9-2.8). Magnetic resonance imaging of the brain undertaken at 1 year of age (fig 1) showed bilateral lesions in the basal ganglia, dorsal midbrain, cerebral peduncles and periaqueductal region compatible with a diagnosis of Leigh syndrome. Gastrointestinal and muscle biopsies were normal. Cytochrome oxidase activity was below the level of detection in the spectrophotometric assay $(<1 \mathrm{nmol} / \mathrm{mg}$ protein/min, normal control range, 30$90)$ and in the cytochemical staining (fig 2).

\section{Mutation analysis and retroviral transfection}

In the initial genetic investigation of this patient, mutations were sought in genes known to be involved in defects of cytochrome oxidase biogenesis, SURF1, SCO1 and SCO2, and COX10. The sequence of the SURFl coding region was normal although there were three repeats of the sequence TGCGGGG in intron $l$ of the SURFl gene. This is a polymorphic variant as either three or four repeats are commonly found in normal controls. SCO1 and SCO2 analysis showed only the normal sequence without any polymorphism. Sequencing of COX10 showed three polymorphisms in an otherwise normal sequence; G1223A (rs1050214), C1384T (rs1050215), and G1111A (which we have identified previously in several normal controls).

To assess the possibility of mutations in other cytochrome oxidase assembly factors, the E6/E7 patient line was transfected with retroviral vectors containing the coding regions of COX11, COX15.1, COX17, OXAl, and PET191. Overexpression of these genes showed that only COX15.1 could rescue the biochemical defect. COX/CS activity, expressed as a percentage of control, showed that the activity of the E6/E7 patient line was increased from 30\% (standard deviation, $4 \%)(\mathrm{n}=3)$, to nearly normal levels after transfection: $95 \%(8 \%)(\mathrm{n}=4)$.

The sequence of the COX15.1 cDNA from the COX15 gene revealed an apparently homozygous single base substitution, cC700T. This mutation would change an arginine to tryptophan $(\mathrm{R} 217 \mathrm{~W})$ in exon 5. This arginine residue is conserved across a wide variety of species, including mammals, insects, plants, and fungi. The presence of the mutation was confirmed by sequencing of exon 5, from genomic DNA, which showed similar results (fig 3). The mutation introduces a restriction site for the enzyme StyI and the presence of the mutation was further verified by digesting the exon 5 genomic fragment with this enzyme. The patient DNA was fully digested into two fragments, of $402 \mathrm{bp}$ and $196 \mathrm{bp}$ (fig 4). Homozygosity was confirmed by PCR amplification, sequencing and restriction enzyme digestion of exon 5 from both parents, who were found to be heterozygous for the same mutation (figs 3 and 4).

Table 1 Conditions for PCR amplification of genes involved in cytochrome oxidase biogenesis

\begin{tabular}{|c|c|c|c|c|c|c|}
\hline Gene & Fragment & Reaction & Forward primer & Reverse primer & Annealing & Size \\
\hline \multirow[t]{2}{*}{ SURF 1 (9 exons) } & Exons 1-2 & gDNA-PCR & $5^{\prime}$ tcgtgacctgtcaggatgc & 5' cagacagcaggtggctctg & $56^{\circ} \mathrm{C}$ & $736 \mathrm{bp}$ \\
\hline & Exons 3-9 & RT-PCR & $5^{\prime}$ aggacgtcctcagggtc & 5' catgatccagcataaaggca & $61^{\circ} \mathrm{C}$ & $897 \mathrm{bp}$ \\
\hline \multirow{2}{*}{ COX10 (7 exons) } & Exons $1-5$ & RT-PCR & $5^{\prime}$ gtccogtgaggagagaggac & 5' ccaaggtcagaatggcaact & $62^{\circ} \mathrm{C}$ & $817 \mathrm{bp}$ \\
\hline & Exons 6-7 & RT-PCR & $5^{\prime}$ Httgaggtgccatttgactc & 5' aacccagcaatttctcttcttg & $60^{\circ} \mathrm{C}$ & $797 \mathrm{bp}$ \\
\hline \multirow[t]{2}{*}{ SCOI (6 exons) } & Exon 1 & gDNA-PCR & 5 ' gatggacagagcgactcctt & $5^{\prime}$ aactgggactacccgcaag & $61^{\circ} \mathrm{C}$ & $552 \mathrm{bp}$ \\
\hline & Exons $2-6$ & RT-PCR & 5' agtacccggacgagttatgc & $5^{\prime}$ tgcgagacagtttccttcct & $60^{\circ} \mathrm{C}$ & $948 \mathrm{bp}$ \\
\hline $\mathrm{SCO} 2$ (2 exons) & Exons 1-2 & RT-PCR & $5^{\prime}$ gettcctctcgtgcttggt & 5' taaacgcagcccgittaatg & $61^{\circ} \mathrm{C}$ & $901 \mathrm{bp}$ \\
\hline \multirow[t]{3}{*}{ COX15.1 (9 exons) } & Exons $1-6$ & RT-PCR & 5' Hgtggaagaggtggctgit & 5 ' agacctgctgttccatgage & 58 & $842 \mathrm{bp}$ \\
\hline & Exons 5-9 & RT-PCR & $5^{\prime}$ gacgtgttcttgecctctgt & $5^{\prime}$ Hgaccatttggaaaccactt & & $808 \mathrm{bp}$ \\
\hline & Exon 5 & gDNA-PCR & 5' caagatcccgecactg & 5' gtccccatttaacgaacaat & $60^{\circ} \mathrm{C}$ & $598 \mathrm{bp}$ \\
\hline
\end{tabular}



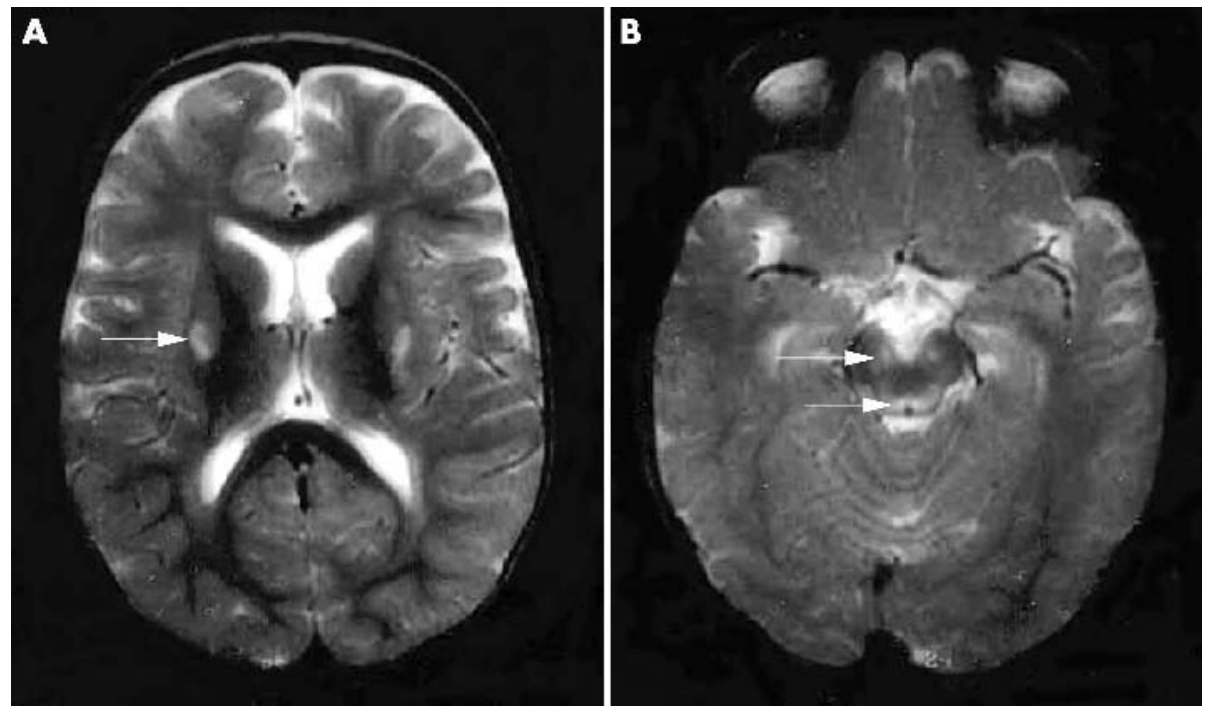

Figure 1 Magnetic resonance imaging of the brain of the patient at age 1 year showed bilateral lesions (indicated by arrows) in the putamina (A) and cerebral peduncles and periaqueductal region (B).

\section{DISCUSSION}

It has been established by biochemical studies in S. cerevisiae that COX15 protein is required for the biosynthesis of the haeme a component of the cytochrome oxidase complex. COX15 is part of a three component mono-oxygenase (ferredoxin, ferredoxin reductase, and COX15) that catalyses the hydroxylation of the methyl group at position eight of the protohaeme molecule. ${ }^{33}$ This reaction is followed by oxidation of the subsequent alcohol into an aldehyde, thought to be carried out by an as yet unknown enzyme. In contrast to the yeast, where there is a single COX15 transcript, the human orthologue has two splice variants, COX15.1 and COX15.2, which differ in the C-terminal domain of the protein and the 3' - UTR of the transcript. The significance of these two splice variants in human beings is at present unknown. ${ }^{29}$

Human cytochrome oxidase deficiency due to mutation in the COX15 gene has recently been identified in a patient with fatal infantile hypertrophic cardiomyopathy and seizures. ${ }^{19}$ The patient was found to be a compound heterozygote with a splicing mutation in intron 3 (C447 -3G) on one allele and the same missense mutation as found in the present patient on the other. In this second patient, who was homozygous for a $\mathrm{R} 217 \mathrm{~W}$ mutation in the COX15 gene, there was a more specific effect on brain function, as the presentation and neuroradiology were characteristic of Leigh syndrome. The identification of another genetic cause of this syndrome increases still further the genetic heterogeneity of this condition in particular, and of cytochrome oxidase deficiency in general. The frequency of COX15 mutation is at present unknown. In 25 cytochrome oxidase deficient patients studied to date, functional complementation by a COX15.1 retroviral vector has resulted in identification of one other case apart from the one reported previously ${ }^{19}$ and the present patient.

Genetic heterogeneity in Leigh syndrome is well established. It is known that enzymatic defects at a number of different stages of substrate oxidation and oxidative phosphorylation can result in a similar pattern of neuropathological lesions, categorised as "Leigh or Leigh-like". However, because the distribution of such lesions can vary substantially from one case to another, attempts have been made to correlate specific neuroradiological patterns with the different genetic defects. Although there is broad overlap, brain stem and subthalamic lesions have been commonly found in patients with SURF1 mutations, ${ }^{34}$ while basal ganglia lesions have been reported to be more common in non-SURFl
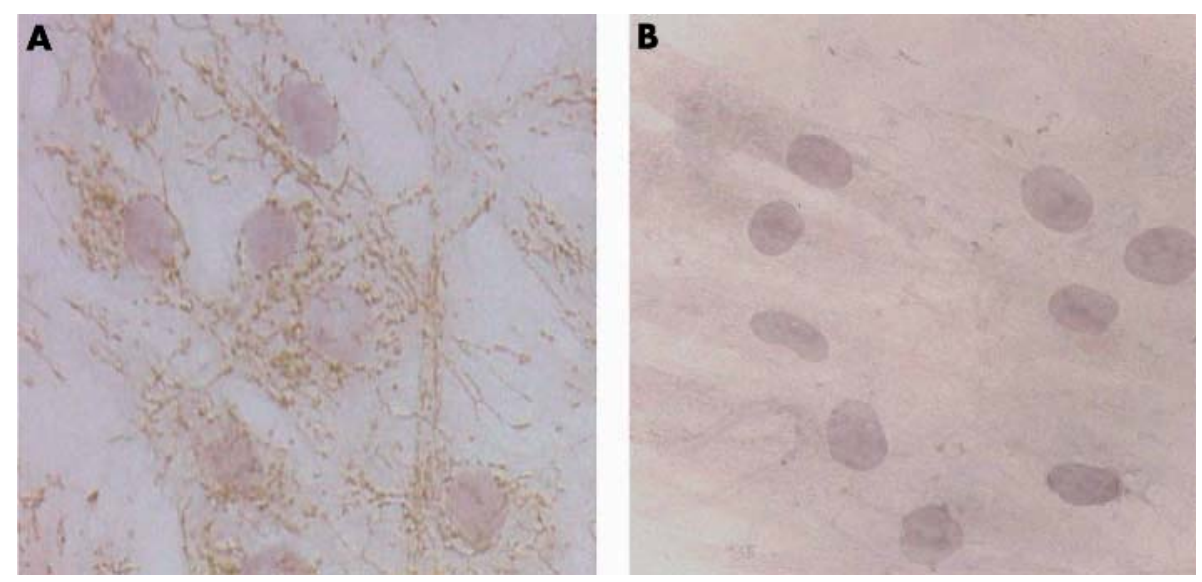

Figure 2 Cytochrome oxidase enzyme cytochemical staining of primary fibroblasts. In the normal control fibroblasts (A), cytochrome oxidase activity is demonstrated as a deposit of specific brown reaction product in a mitochondrial distribution. In the patient's fibroblasts (B), there is no detectable specific reaction product. The cell nuclei are counter stained with haematoxylin. 
A

C C C A T G A C A T C C C T C G G G T C A G T C A G T A
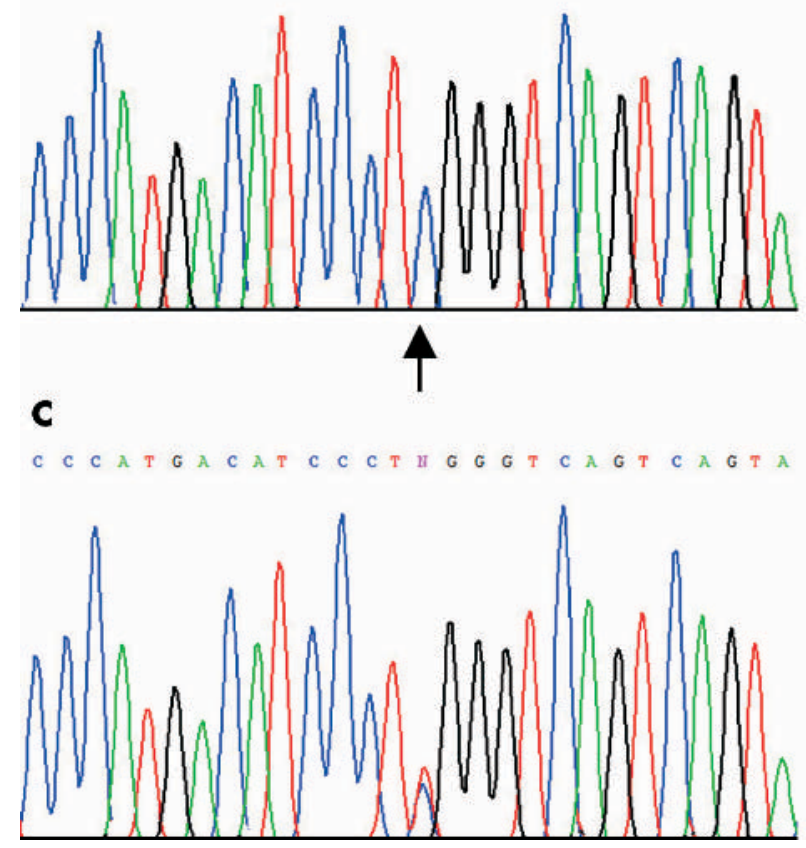

B

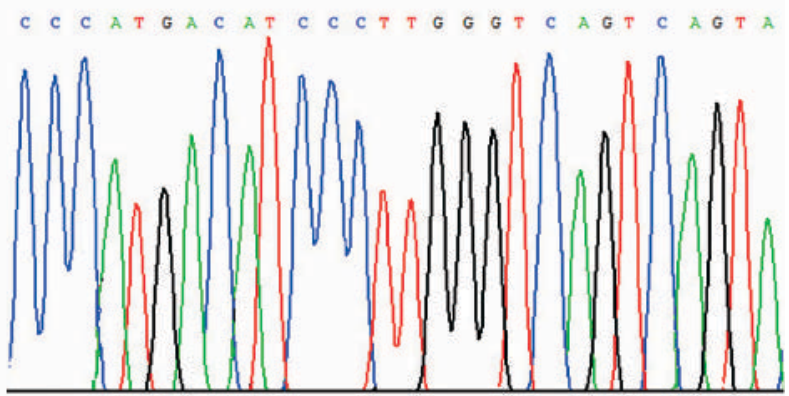

D
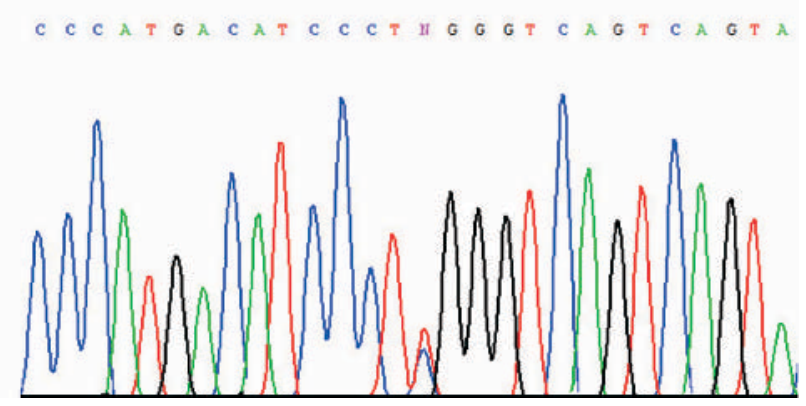

Figure 3 COX15.1 sequencing in genomic DNA. Exon 5 of the COX15.1 gene in a normal control (A), the patient (B), and his parents (C and D). The site of the mutation is shown by the arrow in the normal control sequence. The patient is apparently homozygous for a single base substitution of $\mathrm{T}$ for $\mathrm{C}$. The same substitution is present, in heterozygous form, in both parents.

cytochrome oxidase deficient patients and patients with defects in Complex I or Complex III, combined respiratory chain defects, pyruvate dehydrogenase deficiency, or mtDNA mutations. ${ }^{35}$ In the patient described here, neuroradiological lesions were found in both the basal ganglia and brain stem, indicating that it is not possible to predict a likely genetic cause from the pattern of neuropathology.

It is also important to note that in many instances, these lesions in the brain are part of a wider condition in which function of other systems, such as the haematopoietic system, ${ }^{6}$ cardiovascular system, ${ }^{36}$ extrapyramidal tracts, ${ }^{37}$ peripheral nerves, ${ }^{38}$ or the liver, ${ }^{39}$ is also compromised. In this patient with Leigh syndrome due to a mutation in COX15, there were also symptoms and signs of gastrointestinal tract dysfunction, although the pathological basis for this was not determined. This is a novel association of unknown significance, however gastrointestinal dysfunction is a feature of some mitochondrial diseases, particularly MNGIE syndrome, ${ }^{40}$ so it is possible that there is a causal connection.

Initial descriptions of patients with mutations in genes for cytochrome oxidase assembly factors suggested the possibility that different gene defects might be associated with specific patterns of tissue involvement, even though there is usually a systemic biochemical defect. ${ }^{16-19}$ Subsequent patient reports, including the present one, indicate that there may be considerable clinical and biochemical heterogeneity among patients with mutations in the same gene. ${ }^{6}$ As the number of cases of individual genetic defects is at present quite small, it will require identification of many more cases before it is clear whether any are associated with a specific phenotype. In patients with typical Leigh syndrome and cytochrome oxidase deficiency, analysis of the SURFl gene is indicated in the first instance. However, in other patients it may prove that a general screening method, such as the retroviral

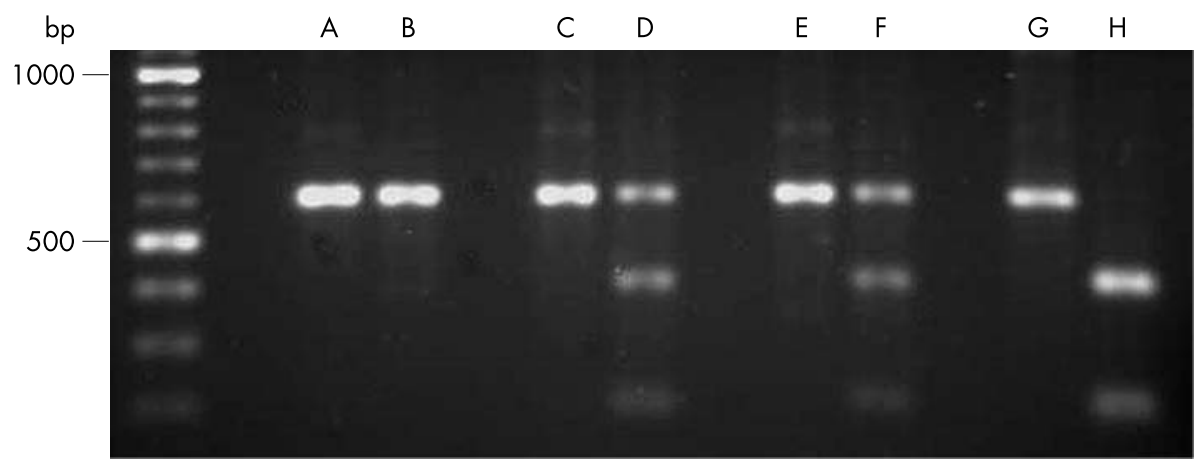

Figure 4 Styl restriction digests of COX15.1 exon 5. The COX15.1 exon 5 PCR product was analysed for the presence of the Styl site which is generated by the mutation. Paired samples are shown of a normal control $(A, B)$, the patient's father $(C, D)$, patient's mother $(E, F)$ and the patient $(G, H)$. In each case the undigested PCR product is on the left and the Styl digest to the right. 
expression system used in this case, will be particularly useful as the genetic defect may not be predictable from the clinical and biochemical presentation.

\section{ACKNOWLEDGEMENTS}

We thank T Johns for excellent technical assistance.

\section{Authors' affiliations}

C E Oquendo, G K Brown, Genetics Unit, Department of Biochemistry, University of Oxford, UK

H Antonicka, E A Shoubridge, Department of Human Genetics, McGill University, Montreal, Canada

W Reardon, Our Lady's Hospital for Sick Children, Dublin, Ireland

This research was supported by grants from the Wellcome Trust to GKB and from $\mathrm{CIHR}$ to EAS. HA holds a postdoctoral fellowship from the MDAC-CIHR partnership. EAS is an International Scholar of the HHMI and a Senior Investigator of the ClHR.

Conflicts of interest: none declared.

Correspondence to: Dr G K Brown, Genetics Unit, Department of Biochemistry, University of Oxford, South Parks Road, Oxford, OX1 3QU, UK; garry.brown@bioch.ox.ac.uk

Received 10 December 2003

Accepted for publication 18 January 2004

\section{REFERENCES}

1 Rahman S, Blok RB, Dahl HH, Danks DM, Kirby DM, Chow CW, Christodoulou J, Thorburn DR. Leigh syndrome: clinical features and biochemical and DNA abnormalities. Ann Neurol 1996;39:343-51.

2 Tiranti V, Hoertnagel K, Carrozzo R, Galimberti C, Munaro M, Granatiero M, Zelante L, Gasparini P, Marzella R, Rocchi M, Bayona-Bafaluy MP, Enriquez JA, Uziel G, Bertini E, Dionisi-Vici C, Franco B, Meitinger T, Zeviani M. Mutations of SURF-1 in Leigh disease associated with cytochrome $c$ oxidase deficiency. Am J Hum Genet 1998;63:1609-21.

3 Zhu Z, Yao J, Johns T, Fu K, De Bie I, Macmillan C, Cuthbert AP, Newbold RF, Wang J, Chevrette M, Brown GK, Brown RM, Shoubridge EA. SURF1, encoding a factor involved in the biogenesis of cytochrome c oxidase, is mutated in Leigh syndrome. Nat Genet 1998;20:337-43.

4 Sweeney MG, Hammans SR, Duchen LW, Cooper JM, Schapira AH, Kennedy CR, Jacobs JM, Youl BD, Morgan-Hughes JA, Harding AE. Mitochondrial DNA mutation underlying Leigh's syndrome: clinical, pathological, biochemical, and genetic studies of a patient presenting with progressive myoclonic epilepsy. J Neurol Sci 1994;121:57-65.

5 Tulinius M, Moslemi AR, Darin N, Westerberg B, Wiklund LM, Holme E, Oldfors A. Leigh syndrome with cytochrome-c oxidase deficiency and a single $\mathrm{T}$ insertion nt 5537 in the mitochondrial tRNATrp gene. Neuropediatrics 2003;34:87-91.

6 Antonicka H, Leary SC, Guercin GH, Agar JN, Horvath R, Kennaway NG, Harding $\mathrm{CO}$, Jaksch $\mathrm{M}$, Shoubridge EA. Mutations in COX10 result in a defect in mitochondrial heme $\mathrm{A}$ biosynthesis and account for multiple, early-onset clinical phenotypes associated with isolated COX deficiency. Hum Mol Genet 2003; 12:2693-702

7 Kadenbach B, Jarausch J, Hartmann R, Merle P. Separation of mammalian cytochrome $c$ oxidase into 13 polypeptides by a sodium dodecyl sulfate-gel electrophoretic procedure. Anal Biochem 1983;129:517-21.

8 Bonne G, Seibel P, Possekel S, Marsac C, Kadenbach B. Expression of human cytochrome $\mathrm{c}$ oxidase subunits during fetal development. Eur J Biochem 1993;217:1099-107.

9 Huttemann M, Jaradat S, Grossman LI. Cytochrome c oxidase of mammals contains a testes-specific isoform of subunit Vlb-the counterpart to testesspecific cytochrome c? Mol Reprod Dev 2003;66:8-16.

10 Huttemann M, Schmidt TR, Grossman LI. A third isoform of cytochrome c oxidase subunit VIII is present in mammals. Gene 2003;12:95-102.

11 Ongvarrasopone C, Kennedy JM. Developmentally regulated expression of cytochrome-c oxidase isoforms in regenerating rat skeletal muscle. J Appl Physiol 1998;85:246-53.

12 Parsons WJ, Williams RS, Shelton JM, Luo Y, Kessler DJ, Richardson JA Developmental regulation of cytochrome oxidase subunit Vla isoforms in cardiac and skeletal muscle. Am J Physiol 1996;270:H567-74.

13 Taanman JW, Herzberg NH, De Vries H, Bolhuis PA, Van den Bogert C. Steady-state transcript levels of cytochrome $\mathrm{c}$ oxidase genes during human myogenesis indicate subunit switching of subunit Vla and co-expression of subunit Vlla isoforms. Biochim Biophys Acta 1992;1139:155-62.

14 Van Kuilenburg AB, Van Beeumen JJ, Van der Meer NM, Muijsers AO. Subunits Vlla,b,c of human cytochrome c oxidase. Identification of both 'hearttype' and 'liver-type' isoforms of subunit Vlla in human heart. Eur J Biochem 1992:203:193-9.

15 Tiranti V, Jaksch $M$, Hofmann S, Galimberti C, Hoertnagel K, Lulli L, Freisinger P, Bindoff L, Gerbitz KD, Comi G-P, Uziel G, Zeviani M, Meitinger T. Loss-of-function mutations of SURF-1 are specifically associated with Leigh syndrome with cytochrome c oxidase deficiency. Ann Neurol 1999;46:161-66

16 Valnot I, Osmond S, Gigarel N, Mehaye B, Amiel J, Cormier-Daire V, Munnich A, Bonnefont JP, Rustin P, Rotig A. Mutations of the SCOl gene in mitochondrial cytochrome $\mathrm{c}$ oxidase deficiency with neonatal-onset hepatic failure and encephalopathy. Am J Hum Genet 2000;67:1 104-9.

17 Valnot I, von Kleist-Retzow JC, Barrientos A, Gorbatyuk M, Taanman JW, Mehaye B, Rustin P, Tzagoloff A, Munnich A, Rotig A. A mutation in the human heme $A$ :farnesyltransferase gene (COX10) causes cytochrome $c$ oxidase deficiency. Hum Mol Genet 2000;9:1245-9.

18 Papadopoulou LC, Sue CM, Davidson MM, Tanji K, Nishino I, Sadlock JE, Krishna S, Walker W, Selby J, Glerum DM, Coster RV, Lyon G, Scalais E, Lebel R, Kaplan P, Shanske S, De Vivo DC, Bonilla E, Hirano M, DiMauro S, Schon EA. Fatal infantile cardioencephalomyopathy with COX deficiency and mutations in SCO2, a COX assembly gene. Nat Genet 1999;23:333-7.

19 Antonicka H, Mattman A, Carlson CG, Glerum DM, Hoffbuhr KC, Leary SC, Kennaway NG, Shoubridge EA. Mutations in COX15 produce a defect in the mitochondrial heme biosynthetic pathway, causing early-onset fatal hypertrophic cardiomyopathy. Am J Hum Genet 2003;72:101-14.

20 Mootha VK, Lepage P, Miller K, Bunkenborg J, Reich M, Hierrild M, Delmonte T, Villeneuve A, Sladek R, Xu F, Mitchell GA, Morin C, Mann M, Hudson TJ, Robinson B, Rioux JD, Lander ES. Identification of a gene causing human cytochrome c oxidase deficiency by integrative genomics. Proc Natl Acad Sci U S A 2003;100:605-10.

21 Saada A, Shaag A, Mandel H, Nevo Y, Eriksson S, Elpeleg O. Mutant mitochondrial thymidine kinase in mitochondrial DNA depletion myopathy. Nat Genet 2001;29:342-4.

22 Mandel H, Szargel R, Labay V, Elpeleg O, Saada A, Shalata A, Anbinder Y, Berkowitz D, Hartman C, Barak M, Eriksson S, Cohen N. The deoxyguanosine kinase gene is mutated in individuals with depleted hepatocerebral mitochondrial DNA. Nat Genet 2001;29:337-41.

23 Nishino I, Spinazzola A, Hirano M. Thymidine phosphorylase gene mutations in MNGIE, a human mitochondrial disorder. Science 1999;283:689-92.

24 Yao J, Shoubridge E. Expression and functional analysis of SURF1 in Leigh syndrome patients with cytochrome c oxidase deficiency. Hum Mol Genet 1999;8:2541-9.

25 Hayasaka K, Brown GK, Danks DM, Droste M, Kadenbach B. Cytochrome c oxidase deficiency in subacute necrotizing encephalopathy (Leigh syndrome). $J$ Inherit Metab Dis 1989;12:247-56.

26 Seligman AM, Karnovsky MJ, Wasserkrug HL, Hanker JS. Nondroplet ultrastructural demonstration of cytochrome oxidase activity with a polymerizing osmiophilic reagent, diaminobenzidine (DAB). J Cell Biol 1968:38:1-14

27 Capaldi RA, Marusich MF, Taanman JW. Mammalian cytochrome-c oxidase: characterization of enzyme and immunological detection of subunits in tissue extracts and whole cells. Methods Enzymol 1995;260:117-32.

28 Srere P. Citrate synthase. Methods Enzymol 1969;13:3-11.

29 Petruzzella V, Tiranti V, Fernandez P, lanna P, Carrozo R, Zeviani M. Identification and characterization of human CDNAs specific to BCS1, PET112, SCO1, COX15, and COX11, five genes involved in the formation and function of the mitochondrial respiratory chain. Genomics 1998;54:494-504.

30 Markowitz D, Goff S, Bank A. Construction and use of a safe and efficient amphotropic packaging cell line. Virology 1988;167:400-6

31 Miller $A D$, Buttimore $C$. Redesign of retrovirus packaging cell lines to avoid recombination leading to helper virus production. Mol Cell Biol 1986;6:2895-902.

32 Lochmuller $\mathbf{H}$, Johns T, Shoubridge EA. Expression of the E6 and E7 genes of human papillomavirus (HPV16) extends the life span of human myoblasts. Exp Cell Res 1999;248:186-93.

33 Barros MH, Carlson CG, Glerum DM, Tzagoloff A. Involvement of mitochondrial ferredoxin and Cox15p in hydroxylation of heme O. FEBS Lett 2001;492:133-8.

34 Farina L, Chiapparini L, Uziel G, Bugiani M, Zeviani M, Savoiardo M. MR findings in Leigh syndrome with COX deficiency and SURF-1 mutations. AJNR Am J Neuroradiol 2002;23:1095-100.

35 Savoiardo M, Zeviani M, Uziel G, Farina L. MRI in Leigh syndrome with SURF1 gene mutation. Ann Neurol 2002;51:138-9.

36 Marin-Garcia J, Goldenthal MJ, Filiano JJ. Cardiomyopathy associated with neurologic disorders and mitochondrial phenotype. J Child Neurol 2002; 17:759-65.

37 Cacic M, Wilichowski E, Mejaski-Bosnjak V, Fumic K, Lujic L, Marusic Della Marina B, Hanefeld F. Cytochrome c oxidase partial deficiency-associated Leigh disease presenting as an extrapyramidal syndrome. J Child Neurol 2001;16:616-9.

38 Bruno C, Biancheri R, Garavaglia B, Biedi C, Rossi A, Lamba LD, Bado M, Greco M, Zeviani M, Minetti C. A novel mutation in the SURF1 gene in a child with Leigh disease, peripheral neuropathy, and cytochrome-c oxidase deficiency. J Child Neurol 2002;17:233-6.

39 Leshinsky-Silver E, Levine A, Nissenkorn A, Barash V, Perach M, Buzhaker E, Shahmurov M, Polak-Charcon S, Lev D, Lerman-Sagie T. Neonatal liver failure and Leigh syndrome possibly due to CoQ-responsive OXPHOS deficiency. Mol Genet Metab 2003;79:288-93.

40 Bardosi A, Creutzfeldt W, DiMauro S, Felgenhaver K, Friede RL, Goebel HH, Kohlschutter A, Mayer G, Rahlf G, Servidei S, Van Lessen G, Wetterling T. Myo-, neuro-, gastrointestinal encephalopathy (MNGIE syndrome) due to partial deficiency of cytochrome-c-oxidase. A new mitochondrial multisystem disorder. Acta Neuropathol (Berl) 1987;74:248-58. 